\title{
Effects of chlorphentermine on the rat lung
}

\author{
DONALD HEATH, PAUL SMITH, and P. S. HASLETON \\ The Department of Pathology, University of Liverpool
}

\begin{abstract}
Heath, D., Smith, P., and Hasleton, P. S. (1973). Thorax, 28, 551-558. Effects of chlorphentermine on the rat lung. Chlorphentermine hydrochloride ('Lucofen') is a sympathomimetic agent which is used in the treatment of obesity at a dosage of $25 \mathrm{mg}$ thrice daily. When this drug, which is available on the British market, was administered intraperitoneally to rats in a dosage of $50 \mathrm{mg}$ per $\mathbf{k g}$ body weight for 50 days, they all developed striking pathological changes in the lungs. Numerous large cells with foamy cytoplasm appeared in the alveolar spaces. Groups of them clumped together and disintegrated to pack the alveoli with granular eosinophilic material. The identification of these cells proved to be difficult even by electron microscopy, and this ultrastructural study is described separately in the following paper. During our acute experiments the rats did not develop right ventricular hypertrophy or hypertensive pulmonary vascular disease.
\end{abstract}

Chlorphentermine hydrochloride (p-chloro- $\alpha \alpha-$ dimethylphenethylamine hydrochloride) is an appetite suppressant marketed under the trade name of Lucofen SA. Its structural formula is shown (Fig. 1). It is a sympathomimetic agent which is claimed to have little stimulant effect on the central nervous system (Martindale, 1972). Since 1968 there has been great controversy as to whether anorexigens may give rise to pulmonary hypertension. The drug aminorex fumarate has been considered a possible cause of the epidemic of primary pulmonary hypertension that began in Switzerland, Austria, and West Germany in 1967 about two years after the drug became available to the public. We have reviewed the evidence for this in a recent paper (Kay, Smith, and Heath, 1971). Chlorphentermine belongs to a group of drugs very similar in structure to amphetamine

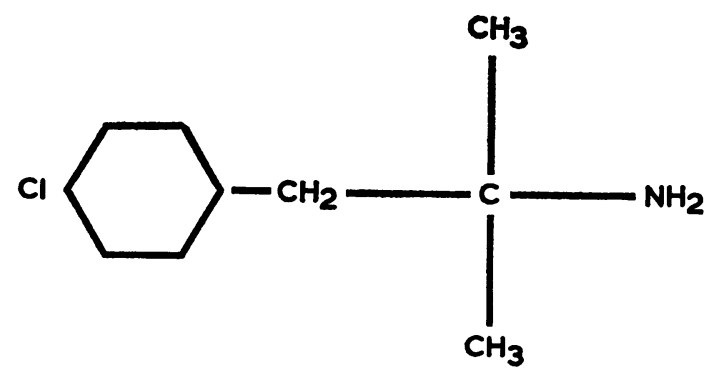

FIG. 1. Structural formula of chlorphentermine hydrochloride.
(Fig. 2) and less similar to aminorex. The drug has the added interest of being on the market at present in Great Britain. For these reasons we decided to study the effects of chlorphentermine on the lungs of rats.

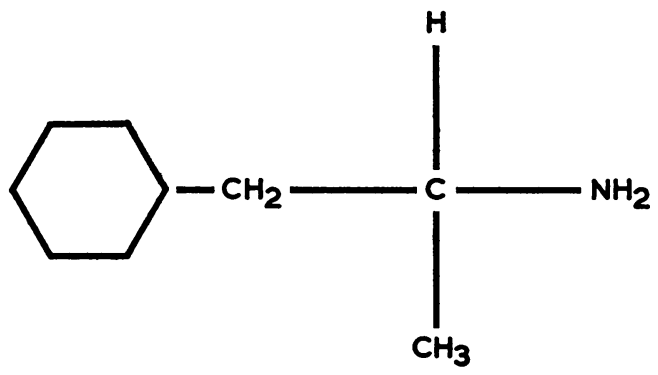

FIG. 2. Structural formula of amphetamine.

\section{METHODS AND MATERIALS}

Chlorphentermine hydrochloride was administered intraperitoneally to 20 male Sprague Dawley rats for a period of 50 days. The drug was given as a solution in physiological saline at a concentration of $10 \mathrm{mg}$ per $\mathrm{ml}$. A dose of $50 \mathrm{mg}$ per $\mathrm{kg}$ body weight was given by intraperitoneal injection daily for six days in each week. Six control male rats of the same strain were also studied. They received intraperitoneal injections of similar volumes of physiological saline only on each occasion when the test rats received injections of the drug. Control and test animals had access to an unrestricted diet of Oxoid breeding pellets and water.

On the fiftieth day of the experiment the rats were killed with intraperitoneal injections of $50 \mathrm{mg}$ amylo- 
barbitone sodium. Small blocks of tissue were taken from the superior lobe of the right lung and placed in ice-cold buffered glutaraldehyde for the electron microscope study described in the following paper (Smith, Heath, and Hasleton, 1973). The bronchus to that lobe was then ligated. The remaining lobes of the right lung (middle, inferior, and median) and the left lung were then distended with $10 \%$ formol saline until the pleural surfaces were smooth.

When fixation was complete the heart was opened. Blood and excess fixative were removed by blotting with fine gauze, and the cardiac chambers were divided using the method described by Fulton, Hutchinson, and Jones (1952). The free wall of the right ventricle was dissected from the remainder of the heart and weighed. The left ventricle with the attached interventricular septum was also weighed, and the two atria were weighed together. The presence of right ventricular hypertrophy was assessed by expressing the weight of the free wall of the right ventricle as an inverse ratio of the weight of the left ventricle and interventricular septum. The use of this ratio excludes the influence of body weight in making comparisons of right ventricular mass. The greater the degree of right ventricular hypertrophy, the smaller the ratio of left-to-right ventricular weight. Right ventricular weight was also expressed as a direct ratio of total body weight.

The pulmonary trunk and ascending aorta were dissected free from the heart and embedded in paraffin wax. Transverse sections of both arteries were cut at $5 \mu \mathrm{m}$ thickness and stained by Miller's method for elastic tissue with counterstaining by van Gieson's reagents for collagen and muscle. The sections were cut at the same distance from the semilunar valves in each instance so that the thicknesses of the medial coats of the two arteries could be compared. The media in each instance was composed of muscle and elastic tissue and was clearly delineated from the intima and the thick fibrous adventitia, the thicknesses of which were excluded from the measurements. The sections were examined with a microscope fitted with a calibrated eyepiece micrometer. Ten measurements of the medial thickness were made on each artery and from these one mean medial thickness was calculated. The mean medial thickness of the pulmonary trunk (PT) was expressed as a ratio of the mean medial thickness of the aorta (A).

When the lungs were fixed a block of each of these four lobes was embedded in paraffin wax. Sections $5 \mu \mathrm{m}$ in thickness were cut and stained by the Miller method for elastin with a van Gieson counterstain to demonstrate smooth muscle and collagen. These sections were examined with a microscope fitted with a calibrated eyepiece micrometer for measurement of the medial thickness and external diameter of muscular pulmonary arteries. Muscular pulmonary arteries in the rat are between 20 and $350 \mu \mathrm{m}$ in diameter and consist of a muscular media bounded by internal and external elastic laminae. In each case some $\mathbf{3 0}$ arteries, which were virtually circular in transverse section, were measured. The external diameter was taken as the mean of two measurements, at right angles to each other, of the distance between diametrically opposite $\frac{\bar{p}}{\partial}$ points on the external elastic lamina. The medial thick- $\stackrel{\oplus}{\Omega}$ ness was estimated as the mean of four measurements taken at approximately equally spaced points around ${ }^{\infty}$ the vessel wall. The medial thickness was then $\vec{O}$ expressed as a percentage of the external diameter. $A-$ value for the average percentage medial thickness $\vec{\omega}$ (MT\%) in each animal was obtained by totalling all $\stackrel{2}{\rightleftharpoons}$ the percentage medial thicknesses and dividing the sum $\overrightarrow{\vec{x}}$ by the number of vessels examined.

\section{RESULTS}

BODY WEIGHT The results show that chlorphenter-

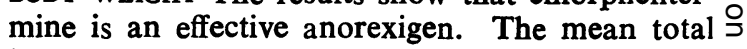
body weight of the controls at the outset was $\vec{C}$ $162 \mathrm{~g}$ and in the course of the experiment these $\mathbb{D}$ rats showed a mean increase in body weight of $\frac{\vec{D}}{D}$ $281 \mathrm{~g}$ to $443 \mathrm{~g}$. In contrast, whereas the initial 3 mean total body weight in the test rats was virtually identical at $161 \mathrm{~g}$ their mean increase in $\overrightarrow{\vec{\varphi}}$ body weight was only $154 \mathrm{~g}$ to give a final weight $\underset{\omega}{\omega}$ of $315 \mathrm{~g}$.

RIGHT VENTRICLE AND PULMONARY CIRCULATION The ranges and mean values of the $L V+S$ ratio, the ratio of right ventricular to total body weight, the PT ratio, and the percentage medial thickness $\overline{\mathbf{A}}$ of 'muscular pulmonary arteries' are shown in Table I. In particular there was no evidence of

T A B L E I

CARDIAC AND PULMONARY RATIOS IN THE CONTROL AND TEST ANIMALS

\begin{tabular}{|c|c|c|c|c|}
\hline \multirow{2}{*}{ Ratio } & \multicolumn{2}{|c|}{ Controls } & \multicolumn{2}{|c|}{ Test Rats } \\
\hline & Range & Mean & Range & Mean \\
\hline$\frac{\mathbf{L V}+\mathbf{S}}{\mathbf{R V}}$ & $2 \cdot 82-4 \cdot 95$ & $4 \cdot 03$ & $2 \cdot 10-5 \cdot 12$ & $3 \cdot 46$ \\
\hline$\frac{\text { RV }}{\text { TBW }}$ & $3 \cdot 76-6 \cdot 15$ & $4 \cdot 81$ & $3 \cdot 93-9 \cdot 93$ & $5 \cdot 81$ \\
\hline$\frac{\mathbf{P T}}{\mathbf{A}}$ & $0.48-0.58$ & 0.52 & $0.44-0.66$ & 0.52 \\
\hline MT $\%$ & $3 \cdot 3-7 \cdot 0$ & $5 \cdot 2$ & $3 \cdot 8-8 \cdot 2$ & $6 \cdot 1$ \\
\hline
\end{tabular}

$\underline{L V}+\mathbf{S}=$ right ventricular weight expressed as an inverse ratio of the RV weight of the left ventricle and interventricular septum $\frac{\mathrm{RV}}{\mathrm{TBW}}=$ ratio of right ventricular to total body weight

$\frac{\text { PT }}{\mathrm{A}} \quad=$ ratio of medial thickness of pulmonary trunk to that of aorta MT $\%=$ percentage medial thickness of muscular pulmonary arteries hypertensive pulmonary vascular disease. The muscular pulmonary arteries were normal with a thin media (Fig. 3). The significance of the results 


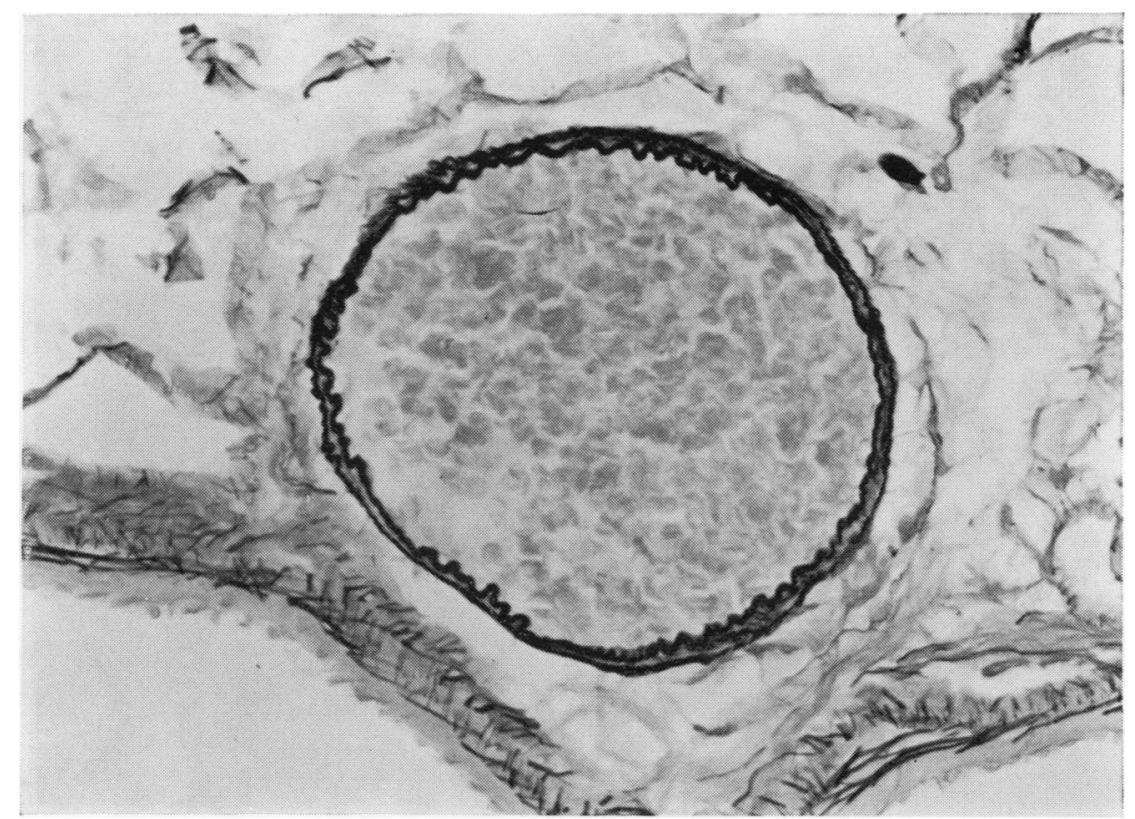

FIG. 3. Test rat. Transverse section of muscular pulmonary artery showing a normal medial thickness. (Elastic van Gieson $\times 375$.)

T A B L E I I

RANGES AND MEAN VALUES OF CARDIAC AND PULMONARY ARTERIAL RATIOS IN WISTAR ALBINO RATS TO WHICH ANOREXIGENS OR AGENTS KNOWN TO PRODUCE PULMONARY HYPERTENSION HAVE BEEN ADMINISTERED

\begin{tabular}{|c|c|c|c|c|c|c|c|}
\hline \multirow{2}{*}{ Agent } & \multicolumn{2}{|c|}{$\mathbf{L V}+\mathbf{S} / \mathbf{R V}$} & \multicolumn{2}{|c|}{$\mathbf{P T} / \mathbf{A}$} & \multicolumn{2}{|c|}{ MT $\%$} & \multirow{2}{*}{ Reference } \\
\hline & Range & Mean & Range & Mean & Range & Mean & \\
\hline $\begin{array}{l}\text { Control } \\
\text { Crotalaria spectabilis } \\
\text { (monocrotaline) }\end{array}$ & $\begin{array}{l}3 \cdot 0-6 \cdot 2 \\
1 \cdot 5-2 \cdot 5\end{array}$ & $\begin{array}{l}4 \cdot 6 \\
2 \cdot 0\end{array}$ & $\begin{array}{l}0.24-0.47 \\
0.68-1.0\end{array}$ & $\begin{array}{l}0.36 \\
0.85\end{array}$ & $\begin{array}{l}3-7 \\
9-20\end{array}$ & $\begin{array}{r}4 \cdot 7 \\
14 \cdot 4\end{array}$ & $\begin{array}{l}\text { Kay and Heath (1969) } \\
\text { Kay and Heath (1969) }\end{array}$ \\
\hline $\begin{array}{l}\text { Intraperitoneal } \\
\text { fulvine }^{2}\end{array}$ & $0.82-1 \cdot 60$ & $1 \cdot 2$ & $1.06-1.47$ & $1 \cdot 2$ & $9 \cdot 6-16 \cdot 6$ & $14 \cdot 3$ & Kay et al. (1971) \\
\hline $\begin{array}{l}10 \% \text { Senecio jacobaea } \\
\text { (Senecionine) }\end{array}$ & $1 \cdot 3-3 \cdot 5$ & $2 \cdot 0$ & $0 \cdot 60-1 \cdot 28$ & 0.9 & $5 \cdot 5-16 \cdot 3$ & $11 \cdot 0$ & Burns (1972) \\
\hline $\begin{array}{l}\text { Aminorex } \\
\text { fumarate }\end{array}$ & $2 \cdot 6-7 \cdot 1$ & $4 \cdot 1$ & $0.35-0.61$ & 0.42 & $2 \cdot 0-6 \cdot 6$ & $3 \cdot 3$ & Kay et al. (1971) \\
\hline $\begin{array}{l}\text { Chlorphentermine } \\
\text { Hypoxia }\end{array}$ & $\begin{array}{l}2 \cdot 1-5 \cdot 1 \\
1 \cdot 2-2 \cdot 4\end{array}$ & $\begin{array}{l}3.5 \\
1.8\end{array}$ & $\begin{array}{l}0.44-0.66 \\
0.69-1 \cdot 18\end{array}$ & $\begin{array}{l}0.52 \\
0.95\end{array}$ & $\begin{array}{l}3 \cdot 8-8 \cdot 2 \\
0 \cdot 5-8 \cdot 2\end{array}$ & $\begin{array}{l}6 \cdot 1 \\
4 \cdot 3\end{array}$ & $\begin{array}{l}\text { This paper } \\
\text { Heath et al. (1973) }\end{array}$ \\
\hline
\end{tabular}

Key to ratios as in Table $I$

Excluding rats 3 and 11 from a series of 15 animals. Rat 3 died at the outset of this experiment.

obtained for these ratios in the present study is best evaluated by comparing them with the ranges and mean values of similar ratios obtained in Wistar albino rats to which anorexigens or agents known to produce pulmonary hypertension have been administered (Table II).

INTRA-ALVEOLAR CELLS Large cells with foamy cytoplasm were present in every section of lung examined from every test animal (Fig. 4). Furthermore, in every section examined such intra-alveolar cells were found in the majority of alveolar spaces. The cells tended to be ovoid in shape, measuring up to $30 \times 15 \mu \mathrm{m}$. Many of the cells occurred singly and had an excentric nucleus (Figs 4 and 5). Other cells had two or more nuclei but it is likely that this appearance was produced by a fusion of the cytoplasm of two or more cells to form a syncytium-like mass (Figs 4, 8, and 9). Individual cells had a foamy appearance due to numerous intracytoplasmic vesicles. Some cells had a dumb-bell shaped configuration consistent with the linking neck of cytoplasm extending through a Cohn's pore (Fig. 5). In many cells 


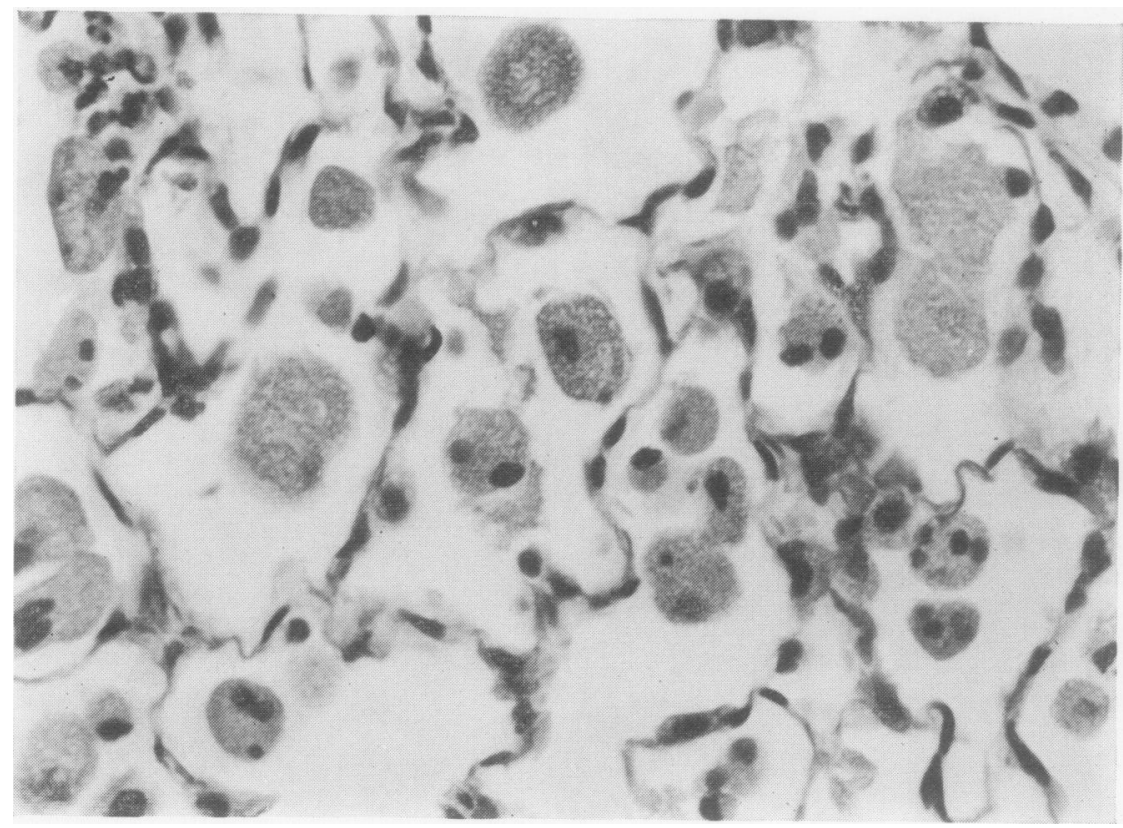

FIG. 4. Test rat. A section of lung showing large 'foam cells' in the intra-alveolar spaces. In some alveoli the cytoplasm of adjacent cells has fused and the nuclei have undergone lysis. (Haematoxylin and eosin $\times 600)$

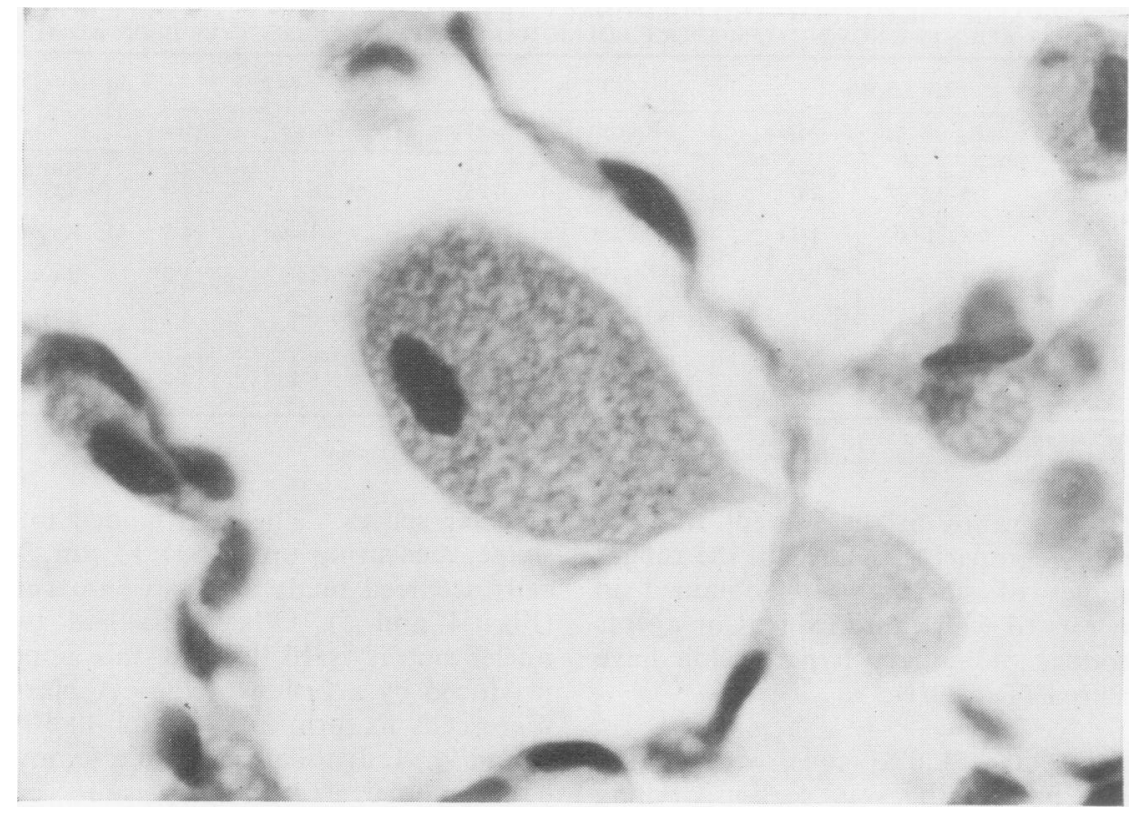

FIG. 5. Test rat. A single 'foam cell' with excentric nucleus and vesicular cytoplasm, an extension of which has herniated through a Cohn's pore. ( $H$ and $E \times 1500)$ 


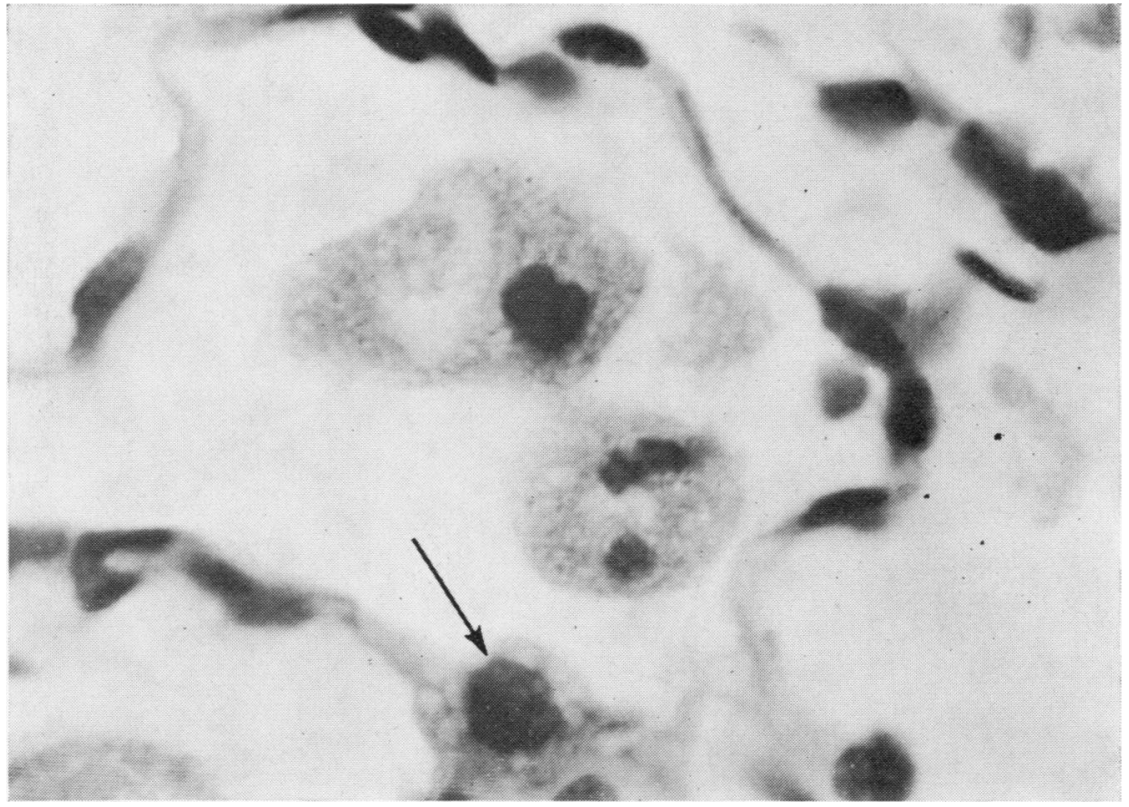

FIG. 6. Test rat. Two intra-alveolar 'foam cells' showing vesicular cytoplasm and larger clear areas. An attached granular pneumocyte is indicated by an arrow. $(H$ and $E \times 1500)$

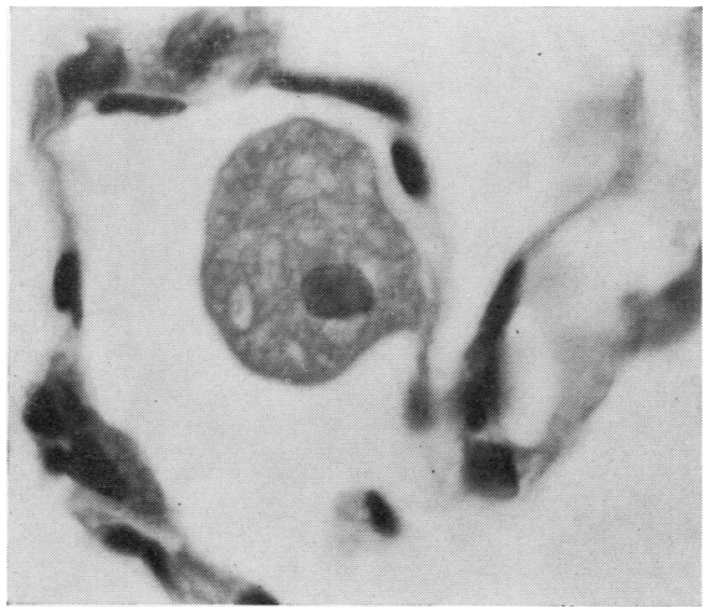

FIG. 7. Test rat. An intra-alveolar cell with intracytoplasmic ovoid clear areas still partly attached to the wall of the alveolus. $(H$ and $E \times 1180)$ 


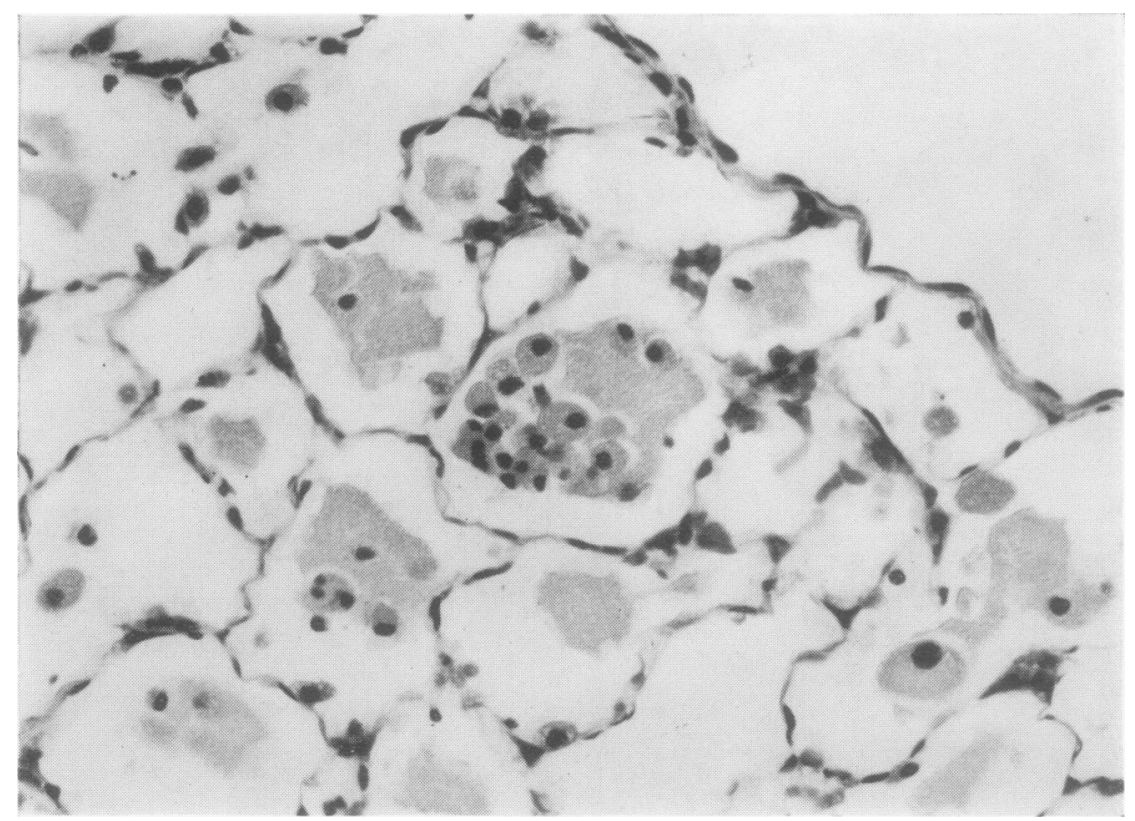

FIG. 8. Test rat. The alveolus in the centre of the picture contains distinct viable cells. Adjacent to it and in the other alveoli are collections of cytoplasmic debris which has resulted from fusion and lysis of cells. ( $H$ and $E \times 375)$

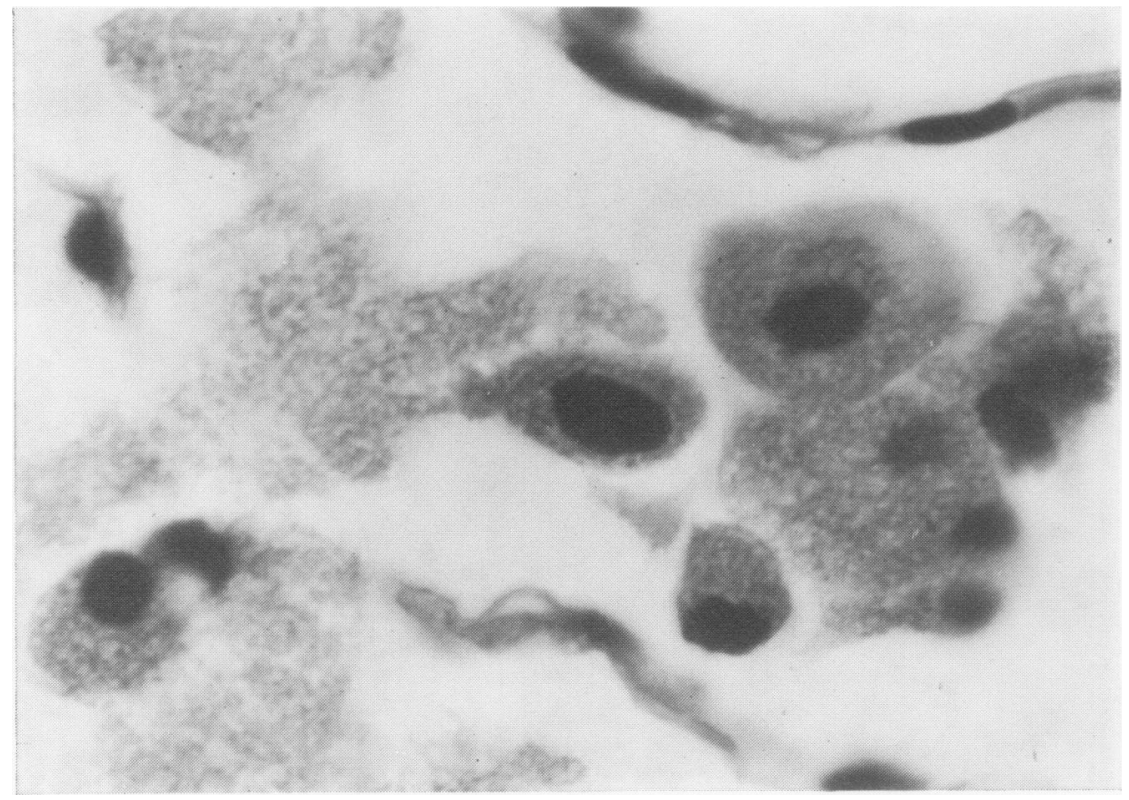

FIG. 9. Test rat. Groups of intra-alveolar cells showing a vesicular cytoplasm with adjacent cytoplasmic debris resulting from the disruption of cells. $(H$ and $E \times 1500)$ 
the clear areas forming the vesicles were larger and appeared to have fused to produce large irregular shaped clear areas (Fig. 6). The vesiculated cytoplasm was similar to that of type II (granular) pneumocytes seen tucked in the corners of pulmonary alveoli (Fig. 6). Some of the cells with excentric nuclei and ovoid intracytoplasmic clear areas were still attached to alveolar walls (Fig. 7). Throughout the lung the granular pneumocytes lining alveolar walls were prominent, forming demilunes with vesicular cytoplasm. In some alveolar spaces groups of cells appeared to have fused to form a syncytial mass, and died with nuclear lysis to leave intra-alveolar granular debris (Fig. 8). At higher magnification this apparently amorphous material still showed the vesicular pattern characteristic of the cytoplasm of the viable cells (Fig. 9).

Some of the intra-alveolar cells in tissue fixed in formalin gave a vivid magenta colour on staining with the periodic acid Schiff reaction. Other alveolar cells, usually smaller, in the same section gave a negative reaction with the PAS stain. The granular debris within the alveoli which had resulted from breakdown of groups of the intraalveolar cells gave a bright cherry-pink reaction with the PAS stain. None of the intra-alveolar cells gave a positive reaction for haemosiderin with the Prussian blue stain. When formalin-fixed material was stained with Sudan black minute intracytoplasmic lipid droplets could be detected.

\section{DISCUSSION}

In this paper we have been concerned mainly with whether or not the anorexigen chlorphentermine hydrochloride gives rise to hypertensive pulmonary vascular disease (HPVD) and right ventricular hypertrophy in rats. By comparing the results of our present investigation in Table $I$ with the results of previous studies in Table II it will be seen that the administration of this drug to Sprague Dawley rats for an acute period of 50 days does not induce HPVD, as occurs with the pyrrolizidine alkaloids monocrotaline, fulvine, and senecionine. The medial thickness of the pulmonary trunk and muscular pulmonary arteries and the ratio of left to right ventricular weight in our rats treated with chlorphentermine are of a quite different order from those which are induced by alkaloids. Similarly, there is no hypertrophy of right ventricle or pulmonary trunk in our animals comparable to that which occurs in states of chronic hypoxia (Table II). The medial thickness of muscular pulmonary arteries in states of chronic hypoxia is irrelevant since under hypoxic conditions medial hypertrophy like that produced by dietary substances does not occur. The various cardiac and pulmonary arterial ratios correspond more closely with those which we have found in control Wistar albino rats and in rats of that strain given aminorex fumarate. In other words, HPVD does not follow the acute administration of chlorphentermine. At the same time it should be noted that in some of the animals the range of values found, as contrasted with mean values, did extend to levels that require further consideration. Thus in some rats we found $\underline{L V+S}$ values as low

$$
\text { RV }
$$

as $2 \cdot 1, \frac{\mathrm{PT}}{\mathrm{A}}$ ratios as high as $0 \cdot 66$, and percentage medial thickness as high as $8.2 \%$.

Although we have shown that the short-term administration of chlorphentermine does not give rise to HPVD, it is clear that this drug produces pronounced changes in the lung parenchyma. There is a striking hyperplasia of the granular pneumocytes lining the alveolar spaces and at the same time numerous cells with foamy cytoplasm appear in the alveoli. These cells were first reported by Franken, Lüllman, and Siegfriedt (1970), who found them in $70 \%$ of all pulmonary alveoli of rats given intraperitoneal injections of chlorphentermine at a dosage of $50 \mathrm{mg}$ of the drug per kg body weight. Their tinctorial reactions were similar to those reported here. We found it impossible to determine the nature of these intraalveolar foam cells on light microscopy and hence we subjected the lung to electron microscopy. These further ultrastructural studies are described in the following paper. They revealed the pathology of chlorphentermine lung to be complex but gave a clearer understanding of its pathogenesis.

From the initial study by light microscopy described here we concluded that the short-term administration of chlorphentermine does not lead to unequivocal HPVD but that its long-term effects on the pulmonary vasculature should be investigated. We also concluded that this drug produces striking effects on the lung parenchyma and we consider the nature of these in the following paper (Smith et al., 1973).

\section{REFERENCES}

Burns, J. (1972). The heart and pulmonary arteries in rats fed on Senecio jacobaea. Journal of Pathology, 106, 187.

Franken, G., Lüllman, H., and Siegfriedt, A. (1970). The occurrence of huge cells in pulmonary alveoli of rats treated by an anorexic drug. Arzneimittel-Forschung, 20,417 . 
Fulton, R. M., Hutchinson, E. C., and Jones, A. M. (1952). Ventricular weight in cardiac hypertrophy. British Heart Journal, 14, 413.

Heath, D., Edwards, C., Winson, M., and Smith, P. (1973). Effects on the right ventricle, pulmonary vasculature, and carotid bodies of the rat of exposure to, and recovery from, simulated high altitude. Thorax, 28, 24.

Kay, J. M., and Heath, D. (1969). Crotalaria spectabilis. The Pulmonary Hypertension Plant, p. 66. Thomas, Springfield, illinois.
Smith, P., Bras, G., and Summerell, J. (1971) Fulvine and the pulmonary circulation. Thorax, 26, 249.

- Smith, P., and Heath, D. (1971). Aminorex and the pulmonary circulation. Thorax, 26, 262.

Martindale, W. (1972). Chlorphentermine hydrochloride. In the Extra Pharmacopoeia, 26th ed., edited by N. W. Blacow, p. 110. The Pharmaceutical Press, London.

Smith, P., Heath, D., and Hasleton, P. S. (1973). Electron microscopy of chlorphentermine lung. Thorax, 28, 559 